\title{
Family Communication and the Choice of a Life Partner Among Youths in Malaysia
}

\author{
NORMAH MUSTAFFA \\ SHAHRUL NAZMI SANNUSI \\ RUZIAN MARKOM \\ Universiti Kebangsaan Malaysia
}

\begin{abstract}
Family communication often becomes an important discourse in the discussion on family function as one of an entity in our society. Parents are the pillars in providing a good environment in the family. Communication among family members and siblings is also found affecting the decision-making process and clear communication between parents and child can bring them to a very positive and effective interaction. McLeod and Chaffee (1972) formulated the quadrant family communication pattern framework namely, permissive, pluralistic, prohibitive and protective. Applying this framework, this study aimed to identify patterns of family communication between parents and their children in the choice of a life partner. Using a survey method, questionnaires were distributed to 400 respondents throughout Peninsular Malaysia and analyzed using Statistical Packages for Social Science (SPSS) version 23. The mean analysis was performed to identify the most dominant family communication patterns when discussing marriage matters. The study found that protective family communication pattern showed the highest level of practice among all communication patterns and have proven to be a significant contributor for Malaysian youth on their decisions towards marriage and life partner choices. The results from this study contribute to the understanding of the importance of communication among family in the decision making with regards to marriage. The present study adds to the existing knowledge on the importance of communication among family members and provides direction for future research work in this area.
\end{abstract}

Keywords: Family communication, pattern, youth, marriage, protective family.

\section{INTRODUCTION}

Marriage has been recognized as the core of unity and harmony in a family. Marriage, regardless of youth or in other age groups, occurred for several reasons that are linked to one another and developed into the pillar of the marriage itself. According to Tamara in Noralina Omar (2008), as a social system, the family contains three subsystems which are, marriage (husband and wife), parents, and siblings, where all that subsystem is influencing and completing each other. Marriage is a life stage that every humankind must go through to perpetuate a legitimate bond between men and women, to carry on the descent, and to improve society's well-being through the family institution. Therefore, the marriage affair in this country should be given serious attention through several efforts to increase public awareness regarding the importance of maintaining a durable marriage that lasts a lifetime and constantly guided by Shari'a. Many parties have taken the initiatives to strengthen these efforts, for example, mass media has justified many examples of the mithali family as the reference or role model for our community (Norsaadah Din et al., 2014). This is because many aspects are needed when it comes to establishing a household and stepping into the realm of marriage, especially in terms of choosing a life partner. 
A mistake in choosing a suitable life partner will cause irreconcievable differences such as conflict, friction, violence, and other disagreements that often lead to divorce. This should be a matter of concern as divorce cases in Malaysia continue to increase almost every year. The Department of Statistics Malaysia has released statistics on marriage and divorce in Malaysia as shown in Table 1.

Table 1: Statistics of Malaysian Marriage Age in 2017

\begin{tabular}{ccc}
\hline Male & Age Group & Female \\
\hline $0.8 \%$ & $>65$ & $0.2 \%$ \\
$0.6 \%$ & $60-64$ & $0.2 \%$ \\
$1.1 \%$ & $55-59$ & $0.5 \%$ \\
$1.5 \%$ & $50-54$ & $0.9 \%$ \\
$2.2 \%$ & $45-49$ & $1.5 \%$ \\
$4.1 \%$ & $40-44$ & $2.6 \%$ \\
$8.7 \%$ & $35-39$ & $5.8 \%$ \\
$21.4 \%$ & $30-34$ & $14.9 \%$ \\
$41.3 \%$ & $25-29$ & $40.2 \%$ \\
$17.1 \%$ & $20-24$ & $28.4 \%$ \\
$1.2 \%$ & $<20$ & $4.6 \%$ \\
\hline
\end{tabular}

The statistics above show that majority of youth in Malaysia, either male or female, married at the age of 25 until 29 , or $41.3 \%$ of males and $40.2 \%$ of females in percentage. In 2017, marriage rates of a male in Malaysia are $47.2 \%$ and female $44.0 \%$ but divorce rates in the same year showed a high percentage as well, $6.5 \%$ in males and $7.0 \%$ in females (The Department of Statistics Malaysia, 2018). The highest rate of divorce cases is found among the couples within the age group of 30-34, which is still considered as a youth in the context of this research. Youth in this research is defined as those between the age of 18 to 35 years old. Assuming the majority of youths in Malaysia are having their marriage at the age of 2529 , it can be concluded that their period of marriage only lasted in a very short time. Moreover, despite the highest rate of divorce is found in the 30-34 age group, the statistics showed that at the same time, the divorce rate for youths within the 25-29 age group indicates a very significant number. In detail, the statistics on divorce in Malaysia is presented in Table 2 below.

Table 2: Statistics on Malaysian divorce in 2017

\begin{tabular}{ccc}
\hline Male & Age Group & Female \\
\hline $2.9 \%$ & $>65$ & $0.9 \%$ \\
$2.4 \%$ & $60-64$ & $1.3 \%$ \\
$4.5 \%$ & $55-59$ & $2.7 \%$ \\
$6.9 \%$ & $50-54$ & $4.7 \%$ \\
$9.9 \%$ & $45-49$ & $8.0 \%$ \\
$13.9 \%$ & $40-44$ & $12.1 \%$ \\
$18.6 \%$ & $35-39$ & $17.3 \%$ \\
$22.0 \%$ & $30-34$ & $23.4 \%$ \\
$14.3 \%$ & $25-29$ & $19.4 \%$ \\
$4.4 \%$ & $20-24$ & $9.1 \%$ \\
$0.2 \%$ & $<20$ & $1.2 \%$ \\
\hline
\end{tabular}

Hamidah Ab. Rahman in Noor Syaibah (2016) stated the most significant contributors to divorce are communication problems, financial issues, urbanization, and unemployment. Communication problems as one of the major causes of divorce may occur by the difference 
of conception between the couples in understanding the nature of marriage. It might happen when families or in this case, parents, did not give them a clearer explanation regarding the intricacies of marriage before they choose their life partner and establish a family institution. The latest statistics on the divorce rate released by the Department of Statistics Malaysia in 2019 showed an increase of 12 per cent to 56,975 cases compared to 50,862 cases in the previous year. A report by Berita RTM online indicated that the main factor in the increase of divorce cases in Malaysia was due to the problem of lack of understanding, i.e. lack of communication, in the couple's relationship throughout their marriage, in addition to issues of violence and also financial problems.

In terms of choosing a life partner, either deliberately or not, our communities have already set their criteria as a standard to decide whether the life partner candidate befits their child or not. For example, in the context of Malay society which the majority of them are Muslims, it is mandatory for them to only choose and marry individuals from the same religion and forbid the otherwise, therefore religious similarity is an absolute requirement for them to comply (Saraswati, 2011). Once the main criteria have been fulfilled, it will then lead them to more specific ones such as faith, beauty, prosperity and wealth. The concept of "sekufu" or compatibility also plays an important part for them to choose their life partner. This means both individuals who want to get married should be in equal status to live a balanced and appropriate life in the family they are about to build.

When it comes to choosing a life partner, parents play a very important role in influencing youth decisions as they are the children's first reference, teacher and mentor. The influence can also be in terms of advice for the children on what to consider in choosing a life partner. Although children nowadays are given the freedom to choose their spouse and no longer subjected to the parental decision (Irmayani, 2010), in reality, parents' views and advice often have a significant influence on the children's decision-making process, especially when it comes to choosing a life partner. A family institution built through a marriage bond results from an interpersonal relationship that is positively influenced by high psychological and emotional support (Suryani Yahya et al., 2019). Thus, this research wants to see how the psychological and emotional support aspects play a role in influencing the decision-making among youth, especially in choosing a life partner by identifying their responses to communication patterns applied by their parents.

Therefore, this study aims to identify the parents' communication pattern when it comes to discussing marriage and choosing their children's life partner. It is difficult for us to ascertain the family communication pattern that occurs within parent-children communication towards a marriage. Communication, in this context, is not just about information exchange between parents and children. But it also involved the interactions between both parties that are often accompanied by a variety of meanings and are not limited to exchanging information or conveying states of mind only. Ambert (2001) stated that the relationship between parents and children is a transactional process, which leads to influence on one another. According to Koerner and Fitzpatrick (2002), family communication patterns can create different effects on youth behaviour and psychology. 


\section{Parental Involvement in Life Partner Choice}

\section{LITERATURE REVIEW}

Attempts by parents to influence their children's choice of life partner suggests that parents and children may conflict and not in agreement over what type of person would be the most suitable choice for the youth's life partner. Buunk et al. (2008) found that children rated what was assumedly a lack of genetic quality in a potential romantic partner, such as being physically unattractive, lacking a sense of humour, and lacking creativity, as being more unacceptable to themselves compared to their parent's criteria of choice. Conversely, these children also rated a lack of parental investment and cooperation with the ingroup in a potential romantic partner, such as having a different ethnicity, being divorced, and being from a low social class, as more unacceptable to their parents, relative to themselves.

Choosing a life partner and going through the marriage procedures is often a long and tedious process. To understand the influence of the intensity of parental involvement in their children choice of life partner, it is important to relate it to the local customs and culture. Arranged marriage is still common in many Asian countries, either by the matchmaking of the parents or through a go-between. In a study on Japanese parents-children conflict, Dubbs et al. (2013) hypothesize that parents and children have conflicting preferences for the choice of life partner of the child. Young Japanese adults found traits implying a lack of genetic quality as being more unacceptable to themselves, while a lack of parental investment and cooperation with the ingroup was perceived as being more unacceptable to their parents. Japanese young adults, much like many other young adults in other cultures, tend to desire a romantic partner who has traits indicative of genetic quality, while they feel that their parents would prefer for them to have a romantic partner who would be a good parent and a cooperative member of the ingroup.

In Europe, a study by van Zantvliet et al. (2014) on parental involvement among Turkish and Moroccans in the Netherlands, posits that parental involvement is modest among Turkish and Moroccan immigrants, but relatively high when compared with the levels of parental involvement found among the native Dutch. Furthermore, analyses reveal variation in parental involvement within the Turkish and Moroccan groups. Parental involvement is greater among children with lower-educated parents. However, this effect is counteracted by a child's higher educational attainment and formalizing the union at a later age.

\section{Family Communication Pattern}

Family communication often becomes an important discourse in the discussion on family function as one of an entity in our society. Parents are the pillars in providing a good environment in their family. Communication among family members and siblings is also found affecting the decision-making process and clear communication between parents and child can bring them to a very positive and effective interaction. Parents that are implementing two-way communication will allow their child to get closer to them. This situation may give the child ample space to convey their opinion or to comfortably ask their parents' opinion regarding their problems. On the other hand, implementing one-way communication that focuses on parents' authority as the key element of interaction, may lead them to a less friendly relationship as both parties become more reluctant to communicate to each other.

Communication in a family is significantly important as it allows the family members to express their opinion, state their desire, and communicate their problem or anxiety. Open communication based on honesty creates such circumstances that allow each member to embrace the differences between them and to express their love to one another. A study 
conducted by Jamiah Manap et al. (2013) on parental communication in an Exemplary Family stated that family plays a very important role in supporting the psychosocial adaptation of youth and those who are in early adulthood, especially among families with lower income. Open communication in the family is also a contributor to lowering at-risk youth behaviour and at the same time improving their psychosocial adaptation (Jamiah et al., 2013; Zhiwen et al., 2011)

Communication as a basis to identify relationship aspects within a family began its studies in the 1960s and continues to improve until today. According to Baldwin (2012), family communication patterns have been studied in two main dimensions; socio-oriented and concept-oriented. Meanwhile, Aleti et al. (2015) stated that contemporary families believe that a socio-oriented pattern is a negative pattern that emphasizes parental control towards the children, while the concept-oriented pattern that focuses on encouragement is believed to the positive one. Outside the marketing domain, it is explained that parent-children interaction, in the context of socio-oriented pattern, is built based on authority and control, while in contrary, the interaction within the concept-oriented pattern is built upon harmony and encouragement (Ritchie, 1991; Zhang, 2007). Chaplin and John (2015) stated, the sociooriented pattern is more focused on telling the children about the negative effect that might be resulted from their wrongdoing rather than to establish a good and harmonious relationship, while Moschis (1987) also stated that concept-oriented communication pattern is often characterized by a strong parents' encouragement towards the children.

Research by Aziyah Abu Bakar (2008) found that concept-oriented communication pattern with a democratic style of parenting where the parents tend to be more tolerance is proven to bring positive impact to a family function and well-being. This finding was later confirmed by the study of Lampakas (2017) which stated that concept-oriented pattern with democratic parenting style is significant factors that predict the student's interpersonal communication competence. This finding shows, the effectiveness of communication pattern applied in a family is very important to improve the self-competence of the family member itself, especially the children.

\section{Family Communication Patterns Quadrant}

In the earlier 1970s, a new conceptual framework explained an advanced approach in understanding family communication patterns. A concept called four matrix quadrants introduced by McLeod and Chaffee in 1972. This concept believed, the family communication patterns have changed over times. Therefore, McLeod and Chaffee (1972) have formulated a new model consisted of four main dimensions. According to the quadrant, family communication patterns can be categorized into four patterns which are permissive family, pluralistic, prohibitive and protective.

The first dimension is permissive. The permissive family pattern is known as a pattern that implementing low control and encouragement towards the children's perception and behaviour. This means, the parent-child communication in the decision-making process only required very less interaction (Chan \& McNeal, 2003; Moschis, 1987, Rose et al., 1998). These families represent absolute freedom and are characterized as less concerned. Niemi (1998) believed that the term permissive represents the whole conception of laissez-faire.

At the same time, there is also a spectrum of parental control that does not allow the children to give input on the decision-making process, which is called a prohibitive pattern. Parents will usually tell their children what to think when it comes to deciding something (A 
tells $\mathrm{B}$ regarding what to think about $\mathrm{X}$ ). These families tend to emphasize vertical relationship concept, obedience, parental control and restriction to certain external information (Rose et al., 2002, 1998). As a result, the parents that applied this pattern are more likely to adopt a prohibitive style rather than protecting their children only as needed. This communication pattern suggests one-way and not two-way communication between parents and children. Socio oriented communication pattern can be seen among most Asian families, especially in China and India where most parents in the family system within these countries tend to seek conformity in every aspect of life (Trubisky et al., 1991; Siu Man, 2002; Zhang et al., 2005; Zhang et al., 2007; Alpa Arora, 2010; Aziyah et al., 2013). Thus, children in Asian family are likely to be more submissive and obedient towards rules and regulations set by their parents. It is also found that they have higher self-discipline and respect for older people.

The third pattern of family communication is open family or often called pluralistic. Pluralistic family encourage an open discussion regarding ideas or decision making. Pluralistic parents tend to be more open-minded and focusing on maintaining mutual understandings between all family members, in other words; relationship-oriented (Chan \& McNeal, 2003; Rose et al., 1998). In quadrant, it is shown, communication between $A$ and $B$ is marked with 2 reciprocal arrows, which signifies two-way communication. Pluralistic communication can be categorized as one of concept-oriented pattern which is characterized by parents' encouragement towards their children to decide everything relied on their consent and put aside any restriction for children to express themselves.

Studies on families in the western countries showed most families are using conceptoriented communication pattern rather than the socio-concept pattern which emphasizes conformity and obedience (Dumlao et al., 2000, Allison \& Schultz, 2004; Koerner \& Fitzpatrick, 2004; Bexter et al., 2005 in Aziyah et al., 2013). Parents' attitude in western families is likely to be more open in considering children's opinion, more tolerant and are more willing to compromise children's behaviour. As a result, children that are raised in an open family tend to acquire a higher level of self-confidence and are easier to adapt in their social life (Kelley et al., 2002; Koerner et al., 2004; Wilson et al., 2004; Wood, 2004; Aziyah et al., 2013).

The last pattern in this typology is protective family, where the communication style applied is a combination of control and encouragement towards object $X$. In this type of family, children (B) will be receiving advice from their parents (A) when they are about to decide something, but in the end, children still have an opportunity to make their own decision. Protective family concepts justify the children to think freely but at the same time parents still have the authority to control children's behaviour by upholding family hierarchy (Moschis, 1987). The nature of this protective pattern may be seen in such circumstances where parents allow their children to express their thoughts and feeling but the final decision often relies on parents' consent. Parents realize that the children also have their interest regarding the discussed issue and they are not reluctant to children's opinion but still play a role in controlling the interaction.

The four family communication patterns by McLeod and Chaffee (1972) as explained above will later be used to identify the most applied communication pattern in a Malaysian youth family when discussing marriage and choosing a life partner. To strengthen and to give a clearer explanation about the domain of this study, the researcher will also use this model of family communication to analyze which factor or pattern plays the most significant role in influencing the youth decision-making process. 


\section{METHODOLOGY}

This research was run quantitatively through a survey by distributing a questionnaire to 400 samples consists of youth in the 18-35 age range who are living in an urban, suburban and rural area in peninsular Malaysia (north, south, east and west zone). The response obtained then were analysed by using Statistical Package for Social Sciences (SPSS) software version 23. This method was chosen as it in line with the research objectives which is to identify the family communication pattern applied when discussing marriage and to analyze whether that applied pattern influence the youth decision-making process or not.

The distributed questionnaire consisted of several sections, which are respondent's demography, McLeod and Chaffe's (1972) family communication pattern dimension (permissive, pluralistic, prohibitive and protective), and also youth decision making aspect. The responses were measured on a Likert scale ( $1=$ extremely disagree, $2=$ disagree, $3=$ less agree, 4= agree, $5=$ extremely agree). To identify the most dominant communication pattern applied in discussing marriage issue, descriptive statistic analysis was done and the most dominant pattern will be determined based on the highest mean score among the four communication patterns. Furthermore, to support the result of descriptive statistics, a linear regression test was conducted to ensure that the communication patterns have indeed played a significant role in influencing the decision-making process of youth, including their decision regarding marriage and choosing a life partner.

\section{Respondent Demographics}

\section{FINDINGS}

Table 3 explains the demography aspects of respondents. Respondent's identities are categorized based on gender, age, educational level and occupation with descriptive statistics to indicate the frequency and percentage.

Table 3: Respondent demographics

\begin{tabular}{lcc}
\hline Demography & Frequency & Percentage (\%) \\
\hline Gender & 129 & 32.3 \\
Male & 271 & 67.8 \\
Female & & \\
Age & 359 & 89.75 \\
$18-23$ & 38 & 9.5 \\
$24-29$ & 3 & 0.75 \\
$30-35$ & & \\
Educational Level & 8 & 2.0 \\
PT3/PMR/SRP & 60 & 15.0 \\
SPM/SMA/SPMV & 20 & 5.0 \\
Basic/Matriculation & 126 & 31.5 \\
Diploma/STPM & 185 & 46.3 \\
Bachelor/Master & 1 & 0.3 \\
PhD & & 76.8 \\
Occupation & 307 & \\
Student & 49 & 12.3 \\
Private sectors & 14 & 3.5 \\
Self-employed & 4 & 1.0 \\
Government & 26 & 6.5 \\
Unemployed & & \\
N = 400 & &
\end{tabular}


From a total of 400 respondents, 129 (32.3\%) of them are male, while 271 (67.8) are female. In terms of age, most of the respondents involved in this research were aged 18-23, as much as 359 youth or 89.75 in percentage, while there are only $38(9.5 \%)$ respondents in the age group 24-29, 3 respondents at the age group of 30-35 years old. Findings on respondent's educational level indicate that most responses obtained in this research were from youth with undergraduate/postgraduate level of education with 185 people $(46.3 \%)$ followed by diploma/STPM level with 126 people (31.5\%), while the fewest number of the respondent was found at the PhD level with only 1 person (0.3\%). In terms of occupation, the majority of respondents in this research or 307 (76.8\%) of them are students, while the least are those who are working in government sectors with 4 people (1.0\%) only.

\section{Communication Pattern and Choosing of Life Partner}

The mean analysis of marriage aspect and choosing of life partner for each independent variable, which is permissive, pluralistic, prohibitive, and protective pattern of family communication, was done to identify which pattern is the most dominant to be applied among youth's families. The most dominant communication pattern later can be identified by looking at the highest number among all variables. The finding is shown in Table 4 below.

Table 4: Mean value of marriage aspects for each variable

\begin{tabular}{llc}
\hline $\begin{array}{c}\text { Communication } \\
\text { Pattern }\end{array}$ & \multicolumn{1}{c}{ Statement } & Mean \\
\hline Permissive & Parents are always tolerant about children's mate & 3.89 \\
Pluralistic & Parents often held an open discussion regarding children's marriage & 4.05 \\
Prohibitive & Parents have decided and arranged children's marriage and life partner & 2.10 \\
& for the sake of their children & \\
Protective & Parents always showed a positive attitude when discussing children's & $4.15^{*}$ \\
& marriage & \\
\hline
\end{tabular}

The mean analysis of marriage aspects in each variable showed the highest number is at the protective family pattern with an average of 4.15. In other words, this pattern is the most applied pattern among parents when discussing marriage issue with their child and choosing the child's life partner. The protective family pattern is characterized by a high level of encouragement and at the same time, control from the parents towards the child. In terms of choosing a life partner this also means, although the final decision regarding the life partner will still be made by the children, that decision should be based on the parents' opinions and consideration. However, both concept-oriented communication pattern; permissive and pluralistic also showed a high mean value, which is 3.89 and 4.05 on average. These findings explained that parents are also very open-minded and allow their children to choose their life partner based on their consent. Meanwhile, a prohibitive family pattern characterized by low encouragement and high control from parents is shown as the least applied pattern, with only 2.10 on average. These findings conclude that parental communication that emphasized parents' absolute authority is no longer practised among Malaysian youth family when discussing marriage and choosing a life partner.

\section{Regression Analysis on Protective Family Pattern and Youth Decision Making}

As explained before, the method applied in this research is divided into two stages, which is to identify the most dominant communication pattern applied in the context of marriage and the choosing of a life partner, and to analyze whether that communication pattern plays a significant role in influencing youth decision making. Thus, linear regression analysis on 
protective pattern dimension towards youth decision making was conducted, with the result as shown in Table 5 below.

Table 5: Regression analysis on protective pattern and youth decision making

\begin{tabular}{cccc}
\hline Variables & Beta & $\mathbf{t}$ & Sig. Value \\
\hline Socio-protective & .344 & & \\
\hline pendent var: Decision-making & & 7.309 & 0.000 \\
\hline
\end{tabular}

Table 5 above explained that the protective family communication pattern is indeed a significant contributor to youth decision making. This is showed by a significant value of $0.000(p<0.05)$ and influencing the youth decision making as much as $34.4 \%$. This finding at the same time, support the previous mean analysis by proving that the protective family communication pattern is a predictor of youth decision making, including youth decision regarding marriage and the choosing of a life partner.

\section{DISCUSSION}

Descriptive statistics analysis on four dimensions of family communication patterns showed that parents within the family of youth who were respondents of this research tend to apply protective family communication pattern when discussing marriage in choosing of life partner with their children. However, parents do have their concerns on some criteria and standards, which has to be obeyed by their children when they are about to choose a life partner. In line with a statement by Velasco (2011), a protective family is characterized by a strong emphasis on obedience to parents and the importance of obeying norms and standards that were socially established in society without even questioning or arguing the reason behind it. Although this pattern emphasizes strict obedience towards parents' protection to avoid such conflicts, the element of encouragement in this pattern would allow the children to make their own decision, as long as that decision follows the guidelines set by parents.

In the context of Malaysian society, where manners and norms are strongly influenced by Islamic values for Malay families, this is quite reasonable as marriage and life partner choosing matters are always seen as sacred, therefore could not be finalised immediately without referring to the instructions written in Al-Qur'an and Al-Sunnah. The concept of "sekufu" or compatibility is strongly emphasized by the parents to put the marriage and choosing of a life partner matters as a high priority. There are certain criteria to be considered, for example, wealth, occupation, educational level or family class of the candidates. Then, there are traditional criteria, for example, whether the candidate is a virgin, married, race, or physical disability (Zamali Tarmudi et al., 2014). The high level of protective family pattern practice among parents in the context of the child's marriage and their selection of life partner can also be caused by their beliefs about family as an institution to establish their well-being, both collectively and individually.

However, it is undeniable that this communication pattern has its disadvantages as well. Parents that implement this communication pattern sometimes tend to make their own decision without considering the children's opinion and consent or even always in denial of explaining the reason behind that decision. Baldwin (2015) stated protective family communication pattern emphasizes obedience towards parents so that children will rarely get the opportunity to express their thoughts as they were not raised and taught to build 
strong confidence to believe in their ideas. This leads them to become indecisive and easy to be influenced by another idea either from inside or outside the family (Osredkar, 2012).

The implementation of a protective communication pattern in a family can be considered as one of the most significant contributors that lead to communication problems that were found as the main cause of divorce cases in Malaysia. This is because communication pattern potentially prevents the youth to fully understand the nature of marriage and a sacred philosophy behind it, which for most of the parents see it as a private matter that should not be discussed with their child. This pattern is also very compelling in allowing the children to choose their life partner not based on their consent but by their parent's consent, the reasons are to build collective well-being and to avoid misleading judgement from the society

Despite the high average value found in the protective family pattern, this study also found that the practising level of the concept-oriented pattern which is permissive and pluralistic patterns also showed a high level of practice, i.e. 3.89 and 4.05 respectively. This means that concept-oriented family communication as a whole, without transforming it into micro-dimensions, is more likely to be implemented by parents, rather than the sociooriented pattern in a prohibitive family pattern which is a sub-dimension of socio-oriented, showed a very small value with only 2.10 in average. This concludes that many parents have an open-minded attitude by giving their children absolute freedom in deciding their way of life, or in this case, in choosing a life partner.

In families that are implementing the pluralistic family pattern, family members are seen to be more open-minded and unlikely to hide their differences in thought, idea and opinion. On the contrary, each member will convey their ideas based on their standpoint and they even do not doubt arguing and expressing disagreement (Solomon \& Theiss, 2013). Research conducted by Noorafshan et al. (2013) found that the concept-oriented and pluralistic communication pattern significantly contributes to youth happiness in Iran, while protective and permissive family communication patterns are not significant in influencing youth happiness.

\section{LIMITATION AND FUTURE RESEARCH DIRECTIONS}

There are certain matters which need to be improved in conducting similar research in future. First, future research should broaden the scope of the study as communication problems do not only exist for Malay youth families only but also exist and felt by youths in families from other racial backgrounds. Second, in terms of methodology, the researcher proposes the application of mixed methods, so the phenomena can be understood both quantitative and qualitatively. The use of qualitative methods such as focus group discussion and in-depth interview will help future researchers to understand the context and the research problem will be explored more widely and deeply. As a final point, the researcher hopes this study will significantly contribute to the development of communication science, particularly those related to family communication patterns.

\section{CONCLUSION}

Overall, a protective family communication pattern was found as the most practised pattern among Malaysian Malay youth's family when discussing marriage and choosing a life partner. This is proven by the high mean value found in this dimension, which is 4.15 . This finding is seen as reasonable and quite related to Malaysian culture as a country which adheres to Islamic value and places high concern on values and norms compliance. This will make the 
parents stricter in controlling the children to ensure they choose an appropriate life partner. This pattern also emphasizes the avoidance of internal conflicts and negative responses which might be received from society.

Once the dominant pattern has been agreed upon, linear regression analysis was then performed to identify whether that communication pattern is a predictor of youth decision making or not. The regression analysis has shown that protective family pattern is indeed a predictor or significant contributor to Malaysian youth decision making, including decisionrelated to marriage and the choosing of a life partner.

\section{ACKNOWLEDGEMENTS}

This research received funding from the Grand Challenge Fund, Universiti Kebangsaan Malaysia (Grant Number: DCP-2017-013/2).

\section{BIODATA}

Normah Mustaffa, is currently an Associate Professor of Journalism at the Centre for Research in Media and Communication, Faculty Social Science and Humanities, Universiti Kebangsaan Malaysia. Email: normahm@ukm.edu.my

Shahrul Nazmi Sannusi, is a senior lecturer of Journalism at the Centre for Research in Media and Communication, Universiti Kebangsaan Malaysia. Email: nazmy@ukm.edu.my

Ruzian Markom is an Associate Professor at the Center for the Study of International Law and Siyar, Faculty of Law, Universiti Kebangsaan Malaysia. Her areas of study are Islamic financial law, consumer law, and new media legal literacy. Email: ruzian@ukm.edu.my 


\section{REFERENCES}

Aleti, T., Brennan, L., \& Parker, L. (2015). Family communication for the modern era: A typology. Young Consumers, 16(4), 367-384.

Allison, B. N., \& Schultz, J. B. (2004). Parent-adolescent conflict in early adolescence. Adolescence, 39(153), 101-119.

Ambert, A.-M. (2001). The effect of children on parents (2nd ed.). Haworth Press.

Aziyah A. Bakar. (2008). Relationships with family communication patterns of parenting styles and family cohesion [Unpublished Master's Thesis, Universiti Putra Malaysia, Selangor].

Baldwin, P. K. (2012). Family communication patterns, resilience and social support among hospice family caregivers [Thesis for Doctor of Philosophy in Communication, George Mason University, US].

Berita RTM Online. (2020). Kes Perceraian Meningkat 12\%. https://berita.rtm.gov.my/index.php/nasional/23746-kadar-penceraian-meningkat

Buunk, A. P., Park, J. H., \& Dubbs, S. L. (2008). Parent-offspring conflict in mate preferences. Review of General Psychology, 12, 47-62.

Chan, K., \& McNeal, J. U. (2003). Parent-child communications about consumption and advertising in China. Journal of Consumer Marketing, 20(4), 317-334.

Chaplin, L. N., \& John, D. R. (2010). Interpersonal influences on adolescent materialism: A new nook at the role of parents and peers. Journal of Consumer Psychology, 20(2), 176184.

Dubbs, S., Buunk, A. \& Taniguchi, H. (2013). Parent-offspring conflict in Japan and parental influence across six cultures. Japanese Psychological Research, 55(3), 241-253. https://doi.org/10.1111/jpr.12003

Dumlao, R., \& Betta, R. (2000). Family communication patterns and the conflict styles young adults use with their fathers. Communication Quarterly, 48(2), 174-189. https://doi.org/10.1080/01463370009385589

Irmayani. (2010). Effectivity of KUBE from the perspective of health communication: Research on family empowerment through KUBE in four Provinces. Center of Social Security, Social Welfare Research and Education Agency.

Jamiah Manap, Sidek Baba, Nik Suryani Nik Ab. Rahman, \& Haniza Rais. (2013). Parental communication approaches in mithali family. Journal of Human Development and Communication, 2, 73-87.

Koerner, A. F., \& Fitzpatrick, M. A. (2002). Toward a theory of family communication. Communication Theory, 12(1), 70-91.

Koerner, A. F., \& Fitzpatrick, M. A. (2004). Communication in intact families. In A. Vangelisti (Ed.), Handbook of family communication (pp. 177-196). Lawrence Erlbaum Associates.

Lampakas, A. L. (2017). Relationship between parenting style and the level of interpersonal communication competency mastery of student in higher educational institutions [Final Thesis for Master in Science, University Putra Malaysia, Selangor].

Malaysian Department of Statistics. (2018). Malaysian press release on marriage and divorce statistics 2018. https://www.dosm.gov.my/v1/index.php?r=column/pdf

McLeod, J. M., \& O'Keefe, G. J. (1972). The socialization perspective and communication behaviour. In K. P. J. Tichenor (Ed.), Current perspective in mass communication research. SAGE Publications. 
McLeod, J. M., \& Chaffee, S. H. (1973). Interpersonal approaches to communication research. American Behavioral Scientist, 16, 469-499.

Moschis, G. P. (1987). Consumer socialization: A life-cycle perspective. Lexington Books.

Niemi, P. M. (1988). Family interaction patterns and the development of social conceptions in the adolescent. Journal of Youth and Adolescence, 17(5), 141-151. https://doi.org/10.1007/BF01537884

Noor Syaibah Shabuddin, Norazilah Johari, Norhasima Abdullah, \& Syazwana Aziz. (2016). Divorce among middle-aged adults couple at Hulu Langat district Islamic religious office (Paidhl): Factor exploratory. Jurnal Sains Sosial @ Malaysian Journal of Social Science, 1, 36-52. http://www.kuim.edu.my/journal/index.php/JSS/article/view/50

Noralina Omar. (2008). Impact of socio-ekonomi to marriage dynamics and parenting quality among Malaysian women. Jurnal Pengajian Melayu, 19(1), 126-142.

Norsaadah Din, Nurzatil Ismah Azizan, Nazneen Ismail, \& Ahmad Nazeer Zainal Arifin. (2014). Membina perkahwinan berdaya tahan sepanjang hayat melalui pendekatan Al-Quran dan Al-Sunnah. e-Jurnal Pengajian Islam KUIS, 7(1), 174-187. http://journal.kuis.edu.my/e-jurnal-pengajian-islam/isu-isu/

Osredkar, P. (2012). The relationship between family communication patterns and an individual's emotional intelligence [Thesis of Department of Communication Studies, University of Portland, United Stated].

Ritchie, L. D. (1991). Family communication patterns: An epistemic analysis and conceptual reinterpretation. Communication Research, 18(4), 548-565. https://doi.org/10.1177/009365091018004005

Rose, G. M., Bush, V. D., \& Kahle, L. (1998). Family communication and children's purchasing influence: A cross-national examination. Journal of Business Research, 55(11), 867873.

Saraswati, P. (2011). Relationship between children's perception of parents' role on the choosing of life partner with children's life partner choosing preference based on socio-economy status among early adolescence. Jurnal Psikologi, 6(1), 347-364.

Solomon, D., \& Theiss, J. (2013). Interpersonal communication: Putting theory into practice Routledge Taylor \& Francis Group.

Suriyani Yahya, Fatayah Yahya, Aina Razlin, \& Mohammad Roose. (2009). Relationship between marriage and self-esteem. Jurnal Kemanusiaan, 13, 30-45. https://jurnalkemanusiaan.utm.my/index.php/kemanusiaan/article/view/199

Trubisky, P., Ting-Toomey, S., \& Lin, S. L. (1991). The influence of individualism-collectivism and self-monitoring on conflict styles. International Journal of Intercultural Relations, $15,65-84$.

van Zantvliet, P.I., Kalmijn, M. \& Verbakel, E. (2014) Parental involvement in partner choice: The case of Turks and Moroccans in the Netherlands. European Sociological Review, 30(3), 387-398. https://doi.org/10.1093/esr/icu045

Wilson, S. R., \& Morgan, W. M. (2004). Persuasion and families. In A. Vangelisti (Ed.), Handbook of family communication (pp. 447). Lawrence Erlbaum Associates, Inc.

Wood, J. T. (2004). Interpersonal communication: Everyday encounters. Thomson Wadsworth.

Zhang, Q. (2007). Family communication patterns and conflict styles in Chinese parent-child relationships. Communication Quarterly, 55(1), 113-128. 
Zhang, Y. B., Harwood, J., \& Hummert, M. L. (2005). Perceptions of conflict management styles in Chinese intergenerational dyads. Communication Monographs, 72, 71-91. https://doi.org/10.1080/0363775052000342535

Zhiwen, X., Xiaoming L., \& Stanton, B. (2011). Perceptions of parent-adolescent communication within families: It is a matter of perspective. Psychology, Health \& Medicine, 16(1), 53-65. 